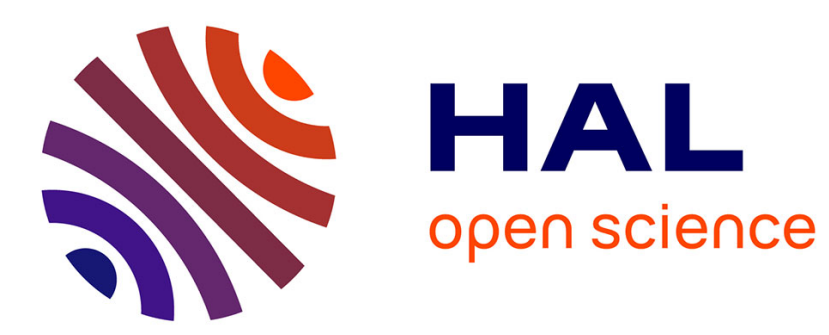

\title{
MOCVD - THE ROUTE TO HIGH PERFORMANCE COMPOUND SEMICONDUCTOR OPTOELECTRONIC DEVICES
}

\author{
R. Griffiths
}

\section{- To cite this version:}

R. Griffiths. MOCVD - THE ROUTE TO HIGH PERFORMANCE COMPOUND SEMICONDUCTOR OPTOELECTRONIC DEVICES. Journal de Physique IV Proceedings, 1991, 02 (C2), pp.C2905-C2-905. 10.1051/jp4:19912108 . jpa-00249786

\section{HAL Id: jpa-00249786 https://hal.science/jpa-00249786}

Submitted on 1 Jan 1991

HAL is a multi-disciplinary open access archive for the deposit and dissemination of scientific research documents, whether they are published or not. The documents may come from teaching and research institutions in France or abroad, or from public or private research centers.
L'archive ouverte pluridisciplinaire HAL, est destinée au dépôt et à la diffusion de documents scientifiques de niveau recherche, publiés ou non, émanant des établissements d'enseignement et de recherche français ou étrangers, des laboratoires publics ou privés. 
Colloque C2, suppl. au Journal de Physique II, Vol 1, septembre 1991

\title{
MOCVD - THE ROUTE TO HIGH PERFORMANCE COMPOUND SEMICONDUCTOR OPTOELECTRONIC DEVICES
}

\author{
R.J.M. GRIFFITHS \\ M.R. Semicon Limited, Melbourn Science Park, Melbourn, \\ Royston, Herts SG8 6EJ, Great Britain
}

\begin{abstract}
Metal Organic Chemical Vapour Deposition (MOCVD) is being used successfully in production and research for the fabrication of III-V and II-VI heterostructures for a wide variety of optoelectronic devices of integrated circuits (OEICs). Photocathodes have been manufactured using MOCVD GaAS/AIGaAs structures for almost 10 years, and most of the solar cells currently in use in space have been fabricated from MOCVD materials. If you own a compact disc player it is more than likely that the GaAs/AlGaAs laser diode was manufactured using MOCVD material. Increasingly the components employed in optical communications systems - lasers, detectors, modulators and waveguides - are being produced using MOCVD prepared GaInAs(P)/InP heterostructures. In the research laboratory considerable progress has been made in combining electronic and optoelectronic device structures on the same InP substrate to creat OEICs, the building blocks for future communication systems. Research into MOCVD of CdHgTe is also now paying dividends, and detector arrays for use in IR imaging systems are being fabricated in CdHgTe structures deposited on CdTe and GaAs substrates. In this talk examples of optoelectronic devices and OEICs will be discussed and the MOCVD equipment employed to prepare the semiconductor structures described.
\end{abstract}

